\title{
Root Rot of Juniperus and Microbiota by Phytophthora lateralis in Oregon Horticultural Nurseries
}

\author{
Ebba K. Peterson, ${ }^{1, \dagger}$ Franziska Rupp, ${ }^{2}$ Joyce Eberhart, ${ }^{2}$ and Jennifer L. Parke ${ }^{1,2}$ \\ ${ }^{1}$ Department of Botany and Plant Pathology, 2082 Cordley Hall, Oregon State University, Corvallis, OR 97331 \\ ${ }^{2}$ Department of Crop and Soil Science, 3017 Agriculture and Life Sciences Building, Oregon State University, Corvallis, OR 97331
}

\begin{abstract}
Widespread symptoms of root rot and mortality on Juniperus communis and Microbiota decussata were observed in two horticultural nurseries in Oregon, leading to the isolation of a Phytophthora sp. from diseased roots. Based on morphology and sequencing the internal transcribed spacer ITS1-5.8S-ITS2 region, isolates were identified as the invasive pathogen Phytophthora lateralis, causal agent of Port-Orford-cedar (POC; Chamaecyparis lawsoniana) root disease. Additional sequencing of the cytochrome c oxidase subunit 1 and 2 genes identified all isolates as belonging to the PNW lineage. Utilizing recovered isolates plus a

in the POC resistance breeding program. Increased aggressiveness was confirmed using a branch stem dip assay with four POC clones that differed in resistance, although no isolate completely overcame major-gene resistance. Isolates were sensitive to mefenoxam, a fungicide commonly used to suppress Phytophthora spp. growth in commercial nurseries. Although POC resistance is durable against these more aggressive nursery isolates, the expanded host range of $P$. lateralis challenges POC conservation through the continued movement of $P$. lateralis by the nursery industry.
\end{abstract} POC-wildlands isolate and susceptible POC as controls, we completed Koch's postulates on potted Juniperus and Microbiota plants. Nursery isolates were more aggressive than the forest isolate, which was used
Keywords: conifer diseases, juniper, Phytophthora root rot, Russian cypress, Siberian cypress
Phytophthora lateralis causes root disease of Port-Orford-cedar (POC; Chamaecyparis lawsoniana), resulting in increased mortality within the range of native POC populations in northwest California and southwest Oregon (Hansen et al. 1999, 2000). POC root disease was first detected in 1923 on ornamental POC plantings in Washington and was found infecting native populations by the 1950s (Betlejewski et al. 2003; Zobel et al. 1985). Although POC has a limited geographic range (Betlejewski et al. 2003), Chamaecyparis spp. are widely planted as an ornamental tree and a windbreak. $P$. lateralis has correspondingly expanded its range, with more recent infections on $C$. lawsoniana plantings and nursery stock in France, The Netherlands, and the United Kingdom (Green et al. 2013; Hansen et al. 1999; Robin et al. 2010; van der Gaag and Meffert 2013). In some cases, $P$. lateralis appears to be spreading via aerially disseminated sporangia, causing foliar infections and aboveground stem cankers (Green et al. 2013; Robin et al. 2010; Schlenzig et al. 2014).

Being an ecologically and economically important forest species, much effort has been directed to reduce the impact of $P$. lateralis on $C$. lawsoniana. The focus has been to isolate noninfested watersheds and to develop resistant POC seed and root stock (Hansen et al. 2000). Resistance in native populations was first apparent in the 1980s. Efforts led by the U. S. Forest Service Dorena Genetic Research Center (DGRC) in Cottage Grove, OR have detected evidence for both quantitative and qualitative resistance (Hansen et al. 1989; Sniezko and Hansen 2001; Sniezko and Koch 2017). Thus far,

${ }^{\dagger}$ Corresponding author: E. Peterson; peterebb@science.oregonstate.edu

GenBank accession numbers: MK780082 to MK780093 and MK792723 to MK792746.

Funding: This project was funded by the United States Department of Agriculture National Institute of Food and Agriculture Specialty Crop Research Initiative (SCRI) program (grant number 2014-51181-22372).

The author(s) declare no conflict of interest.

Accepted for publication 25 November 2019.

(C) 2020 The American Phytopathological Society resistance is durable against all four recognized lineages of $P$. lateralis (Robin et al. 2015).

$P$. lateralis is thought to have a narrow host range (Hansen et al. 2000). POC is the most easily infected and damaged host, although other species have been shown to be susceptible. Other Chamaecyparis spp. display variable degrees of susceptibility (Schlenzig et al. 2014, 2017). P. lateralis has also been isolated from C. obtusa in its presumed native range of Taiwan (Brasier et al. 2010). Pacific yew (Taxus brevifolia) may be killed when growing next to infected cedar trees (DeNitto and Kliejunas 1991; Murray and Hansen 1997). Koch's postulates have been completed for foliar infection of Thuja occidentalis (Schlenzig et al. 2011), with additional reports of foliar infection of other Thuja spp. (Schlenzig et al. 2017).

In the winter and spring of 2014 and 2015, potted conifers displaying symptoms of root disease were observed at two horticultural production nurseries in the Willamette Valley, Oregon (Fig. 1). Losses were reported to be between 60 to $80 \%$ of inventory. P. lateralis was subsequently isolated from the roots of Juniperus communis and Microbiota decussata plants.

Our objectives were to complete Koch's postulates for $P$. lateralis on species of Juniperus and Microbiota. As a potential newly emerging problem, we also sought to determine the lineage of nursery isolates and assess virulence of these isolates on resistant POC. Finally, because disease arose within nurseries despite the application of the oomycete-specific fungicide Subdue MAXX, we also tested nursery isolates for tolerance to the active ingredient, mefenoxam. Mefenoxam-resistant or -tolerant isolates have been reported for numerous Phytophthora spp. (Hu et al. 2008; Hwang and Benson 2005, Lamour and Hausbeck 2003; Olson et al. 2013; Parra and Ristaino 2001; Patel et al. 2016; Pérez-Sierra et al. 2011; Taylor et al. 2002); tolerance could explain the sudden emergence of disease. The overall goal was to determine whether the recovery of $P$. lateralis from these new hosts presents a greater threat to the protection of POC.

\section{Materials and Methods}

$P$. lateralis isolates and lineage determination. Root and crown segments of symptomatic plants (J. communis 'Blueberry Delight' and $M$. decussata 'Celtic Pride' and 'Drew's Blue') were surface sterilized in a $0.5 \%$ sodium hypochlorite solution and plated in Phytophthora-selective media (PARPH; corn meal agar [CMA] plus ampicillin at $200 \mathrm{mg} / \mathrm{liter}$, rifamycin at $10 \mathrm{mg} /$ liter, pentachloronitrobenzene 
[PCNB] at $66.7 \mathrm{mg} / \mathrm{liter}$, hymexazol at $25 \mathrm{mg} / \mathrm{liter}$, and natamycin at $10 \mathrm{mg} /$ liter). After 5 to 7 days of incubation at $20^{\circ} \mathrm{C}$, colonies were transferred to fresh media and pure cultures were maintained on individual plates prior to sequencing.

Different subsets of isolates were used for different experiments (Table 1). Morphological characterization was performed with two isolates from Juniperus (JP-14-1 and JP-14-5) and two from Microbiota (JP-14-7 and JP-15-23). P. lateralis isolate PL3, recovered from C. lawsoniana in Oregon forests, was used as a reference isolate for comparison. Isolate PL3 is currently being used for resistance screening for the DGRC (E. Hansen, personal communication). Chlamydospores were observed from cultures growing on CMA supplemented with $\beta$-sitosterol in the dark at $20^{\circ} \mathrm{C}$ for 3 weeks. Sporangia were produced in water via the methodology described below. For each isolate, we measured the diameter of 20 randomly selected chlamydospores and length and width of 30 randomly selected sporangia under a compound scope at $\times 100$.

DNA was directly extracted from cultures using the Extract-NAmp Plant PCR Kit (MilliporeSigma, St. Louis, MO, U.S.A.). A

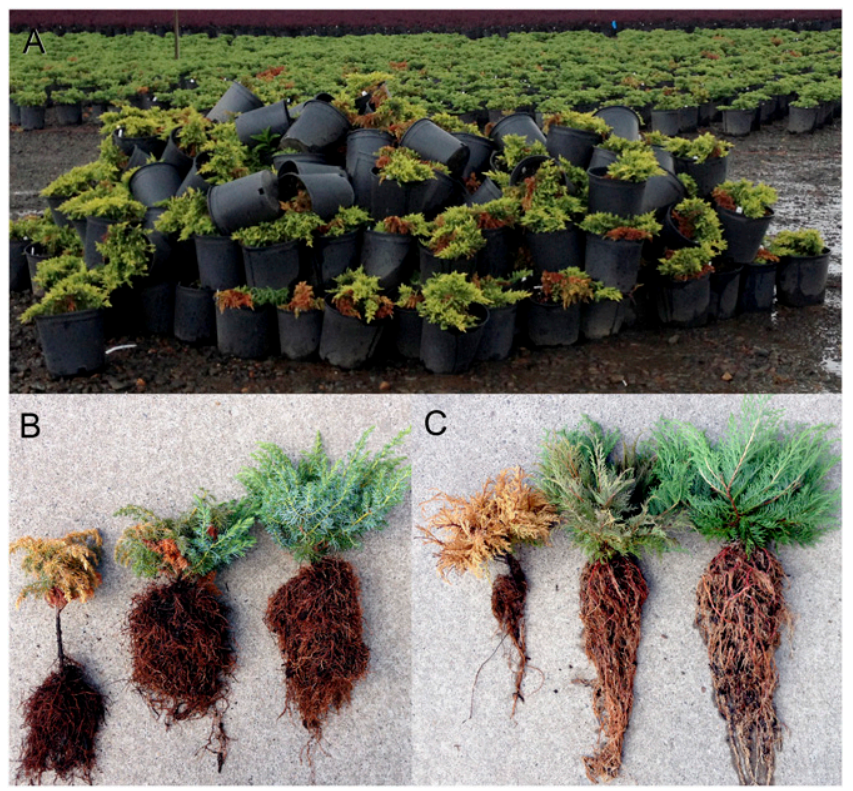

Fig. 1. Disease prevalence in A, Juniperus communis 'Blueberry Delight' and root and crown symptoms observed on B, J. communis 'Blueberry Delight' and C, Microbiota decussata at two horticultural conifer nurseries in which Phytophthora lateralis was recovered.

Table 1. Phytophthora lateralis isolate sources used for experimentation

\begin{tabular}{lllr}
\hline Isolate & \multicolumn{1}{c}{ Host } & \multicolumn{1}{c}{ Source } & Test $^{\mathbf{a}}$ \\
\hline PL3 & \multicolumn{1}{c}{ Chamaecyparis lawsoniana } & Oregon wildlands & $1,2,3,4$ \\
JP-14-1 & $\begin{array}{l}\text { Juniperus communis 'Blueberry } \\
\text { Delight' }\end{array}$ & Nursery A, Oregon & $2,3,4$ \\
& & \\
JP-14-2 & J. communis 'Blueberry Delight' & Nursery A, Oregon & 3,4 \\
JP-14-3 & J. communis 'Blueberry Delight' & Nursery A, Oregon & 3,4 \\
JP-14-4 & J. communis 'Blueberry Delight' & Nursery A, Oregon & 3,4 \\
JP-14-5 & J. communis 'Blueberry Delight' & Nursery A, Oregon & $1,2,3,4$ \\
JP-14-6 & Microbiota decussata & Nursery A, Oregon & 3,4 \\
JP-14-7 & M. decussata & Nursery A, Oregon & $2,3,4$ \\
JP-15-23 & M. decussata & Nursery B, Oregon & $1,2,3,4$ \\
JP-15-24 & M. decussata & Nursery B, Oregon & 4 \\
JP-15-25 & M. decussata & Nursery B, Oregon & 3,4 \\
JP-15-26 & M. decussata & Nursery B, Oregon & 3,4 \\
JP-15-27 & M. decussata & Nursery B, Oregon & 3,4 \\
\hline
\end{tabular}

a Test 1: Koch's postulates; test 2: virulence on Port-Orford-cedar; test 3: mefenoxam resistance; and test 4: lineage determination. small segment of hyphae and chlamydospores were transferred to a $200-\mu l$ PCR tube containing $20 \mu$ l of extraction solution. After incubating at $94^{\circ} \mathrm{C}$ for $10 \mathrm{~min}$ in a thermocycler, $20 \mu$ l of dilution solution was added to this tube. DNA in the extracts was not quantified. Extracts were stored at $-20^{\circ} \mathrm{C}$.

Species identification was first determined for each isolate by amplifying the nuclear internal transcribed spacer (ITS) region using DC6 and ITS4 primers (Cooke et al. 2000; White et al. 1990). For each sample, $0.5 \mu \mathrm{l}$ of template was added to a $15-\mu \mathrm{l}$ PCR volume containing $1 \times$ Phusion High-Fidelity PCR Master Mix with HF Buffer (Thermo Fisher Scientific, Waltham, MA, U.S.A.) and $0.5 \mathrm{mM}$ each forward and reverse primers. PCR was performed on a Bio-Rad DNA Engine Peltier Thermal Cycler with $30 \mathrm{~s}$ of initial temperature of $98^{\circ} \mathrm{C}$; followed by 35 cycles of $10 \mathrm{~s}$ of denaturation at $98^{\circ} \mathrm{C}, 15 \mathrm{~s}$ of annealing at $60^{\circ} \mathrm{C}$, and $20 \mathrm{~s}$ of extension at $72^{\circ} \mathrm{C}$; with a final $5 \mathrm{~min}$ of extension at $72^{\circ} \mathrm{C}$. PCR product was visualized on agarose gels and cleaned with ExoSAP-IT (USB, Cleveland, Ohio, U.S.A.) before submitting for Sanger sequencing. Sequencing was performed at the Center for Genome Research and Biocomputing Core Laboratory at Oregon State University using an ABI Prism 3730 genetic analyzer (Applied Biosystems, Foster City, CA, U.S.A.). Sequences were identified by querying the PhytophthoraID curated database (http://phytophthora-id.org/seq-id.html).

Lineage was determined by sequencing the mitochondrial cox 1 and $\operatorname{cox} 2$ regions for isolate PL3 and all nursery isolates. We additionally obtained DNA extract for seven isolates from E. Hansen to be used as controls. These were of known lineage, as published by Brasier et al. (2012), and included one TWJ isolate, one TWK isolate, one UK isolate, and four PNW isolates (Table 2).

The cox regions were amplified using primers developed by Martin and Tooley (2003) as used in Brasier et al. (2012). The coxl region was amplified using primers FM83 and FM84; FM75 and FM78 primers were used for the cox 2 region. For each reaction, $1.6 \mu l$ of template was added to $18.4 \mu \mathrm{l}$ of a mix containing $1 \times$ reaction buffer, $800 \mu \mathrm{M}$ dNTP, $3.5 \mathrm{mM} \mathrm{MgCl}_{2}, 0.4 \mathrm{mM}$ each forward and reverse primers, and Platinum Taq polymerase enzyme (Invitrogen Inc., Carlsbad, CA, U.S.A.). PCR was performed on a Bio-Rad thermocycler $\left(2 \mathrm{~min}\right.$ of initial temperature of $94^{\circ} \mathrm{C}$; followed by 35 cycles of $1 \mathrm{~min}$ of denaturation at $94^{\circ} \mathrm{C}, 1 \mathrm{~min}$ of annealing at $56^{\circ} \mathrm{C}$, and 2 min of extension at $72^{\circ} \mathrm{C}$; with a final $10 \mathrm{~min}$ of extension at $72^{\circ} \mathrm{C}$ ). PCR product was prepared and submitted for sequencing as described above. Geneious 9.1.6 (https://www.geneious.com) was used to trim and align sequences. Lineages were assigned by comparing the polymorphic nucleotides at the individual loci according to Brasier et al. (2012, see their table 5).

Pathogenicity tests: Koch's postulates. J. communis 'Blueberry Delight' and M. decussata 'Celtic Pride' plants were used for pathogenicity testing. Plants were repotted into $12.7-\mathrm{cm}-$ long $(6.4-\mathrm{cm}$ top diameter) supercell plastic cones (D19L Deepot containers; Stuewe \& Sons, Inc., Tangent, OR, U.S.A.) and left to grow for 3 months in a greenhouse prior to inoculation with zoospores in early February 2016. During this time, we collected root leachate from the plants, which was baited with Rhododendron catawbiense 'Grandiflorum' and POC foliage to further verify no prior Phytophthora infection. Pathogenicity experiments also included as a positive control susceptible OSU-CON1 POC seedlings obtained from the DGRC. These were grown in the 21-cm-long (3.8-cm top diameter) supercell plastic cones (Cone-tainer; Stuewe \& Sons, Inc.).

To produce zoospores for inoculation, three 3 -mm agar plugs containing $P$. lateralis mycelia were placed in the bottom of a petri plate which was flooded with pea broth (dry split pea at $150 \mathrm{~g} /$ liter of deionized [DI] water, autoclaved for $4 \mathrm{~min}$ and strained through cheesecloth before adding $20 \mathrm{mg}$ of $\beta$-sitosterol and reautoclaving for an additional hour). After 1 week, the pea broth was poured off and the colonies were rinsed with DI water before flooding the plate with filter-sterilized creek water. Plates were left at $18^{\circ} \mathrm{C}$ for $24 \mathrm{~h}$ in the dark to induce sporangia formation. If no sporangia were present, the creek water was exchanged, and plates were allowed to sit for an additional $24 \mathrm{~h}$. To induce zoospore release we incubated the plates at $4^{\circ} \mathrm{C}$ for $1 \mathrm{~h}$, then at $20^{\circ} \mathrm{C}$ for $1 \mathrm{~h}$. Zoospores were filtered through 
Miracloth (pore size approximately $25 \mu \mathrm{m}$; MilliporeSigma), then counted with a hemocytometer and diluted for a final concentration with DI water.

We used three different $P$. lateralis isolates for the inoculations (Table 1): JP-14-5, recovered from Juniperus spp., was applied to 13 J. communis 'Blueberry Delight' and 10 OSU-CON1 POC plants; JP15-23, recovered from Microbiota spp., was applied to $15 \mathrm{M}$. decussata 'Celtic Pride' and 10 OSU-CON1 POC plants; and PL3, recovered from C. lawsoniana, was applied to $13 \mathrm{~J}$. communis 'Blueberry Delight', 15 M. decussata 'Celtic Pride', and 10 OSU-CON1 POC plants. Three plants of each species were treated with DI water as a negative control.

At the time of inoculation, plants were removed from the cones and wounded by slashing the outside of the root ball with box cutters on two sides. Each plant, replaced in its cone, was set in a 475-ml plastic cup for inoculation. Because the roots for the Juniperus and Microbiota plants had not yet reached the bottom of the cone, we applied $40 \mathrm{ml}$ of zoospore solution $\left(2.4 \times 10^{4}\right.$ zoospores $\left./ \mathrm{ml}\right)$ to the soil surface. The cup was then flooded with DI water to maintain root zone moisture for $48 \mathrm{~h}$, before removing the cup and resuming a regular watering schedule.

Inoculated plants were incubated in a greenhouse (ambient light, average temperature was $18^{\circ} \mathrm{C}$, and average daily minimum and maximum temperatures were 15 and $23^{\circ} \mathrm{C}$, respectively). No symptoms were observed after 3 weeks for any species; therefore, in early March, we reinoculated the same plants but without the root trimming. Nine weeks after the first inoculation, we rated each plant on a scale of 0 to 2 , where $0=$ healthy, $1=$ symptomatic, and $2=$ dead; the classification was based on aboveground symptoms characteristic of root infection, including branch dieback, chlorosis, and wilting (Fig. 2). We then scraped the outer bark to reveal discoloration of the inner bark characteristic of Phytophthora infection, when present. Lesion margins and root segments of symptomatic plants were plated in PAR (PARPH without the PCNB and hymexazol) to confirm infection (up to five stems per host-isolate combination, for all those that displayed symptoms). For treatments which failed to develop disease, we plated root collars and root segments from two DI water controls or three inoculated plants randomly selected for each host-isolate combination. We sequenced the ITS region of one isolate recovered from each host-isolate combination to confirm positive identification as $P$. lateralis.

Pathogenicity tests: Virulence on POC. To assess the virulence of nursery isolates on resistant POC, we performed a branch stem dip utilizing methodology standard for the initial screening of POC for resistance to $P$. lateralis. We selected four clonal lineages from the DGRC program for testing, representing a range of susceptibility as determined by prior studies. These included OSU-CON1 and OSU-CFI, which are susceptible and resistant clones, respectively, used as standards by the DGRC, and resistant clones COS30839

Table 2. Polymorphic nucleotides from aligned sequences of the mitochondrial cox 1 and cox 2 regions, showing differentiation of the four lineages as described by Brasier et al. (2012)

\begin{tabular}{|c|c|c|c|c|c|c|c|c|c|c|c|c|c|c|c|c|c|c|c|}
\hline \multirow{3}{*}{ Isolate } & \multirow{3}{*}{ Lineage $^{b}$} & \multicolumn{18}{|c|}{ Position of polymorphic nucleotides (bp) in gene $\mathrm{a}^{\mathrm{a}}$} \\
\hline & & \multicolumn{10}{|c|}{$\operatorname{cox} 1$} & \multicolumn{8}{|c|}{$\operatorname{cox} 2$} \\
\hline & & 142 & 151 & 370 & $\mathbf{5 0 5}$ & 544 & 634 & 775 & 952 & 1036 & 1054 & 15 & 123 & 288 & 399 & 435 & 441 & 468 & 498 \\
\hline$\overline{\mathrm{P} 2304}$ & TWJ & $\mathrm{G}$ & $\mathrm{T}$ & A & A & $\mathrm{T}$ & $\mathrm{T}$ & G & $\mathrm{C}$ & $\mathrm{C}$ & A & $\mathrm{T}$ & A & A & A & $\mathrm{T}$ & $\mathrm{T}$ & A & $\mathrm{T}$ \\
\hline P2271 & TWJ & $\mathrm{T}$ & $\mathrm{T}$ & A & G & C & A & $\mathrm{T}$ & C & $\mathrm{T}$ & $\mathrm{T}$ & C & G & C & G & $\mathrm{T}$ & C & C & $\mathrm{T}$ \\
\hline $\mathrm{P} 2271^{\mathrm{c}, \mathrm{d}}$ & unknown & $\mathrm{T}$ & $\mathrm{T}$ & A & $\mathrm{G}$ & $\mathrm{C}$ & A & $\mathrm{T}$ & $\mathrm{C}$ & $\mathrm{T}$ & $\mathrm{T}$ & $\mathrm{C}$ & $\mathrm{G}$ & $\mathrm{C}$ & $\mathrm{G}$ & $\mathrm{T}$ & $\mathrm{C}$ & $\mathrm{C}$ & $\mathrm{T}$ \\
\hline P2149 & TWK & G & $\mathrm{T}$ & $\mathrm{A}$ & $\mathrm{A}$ & $\mathrm{T}$ & $\mathrm{T}$ & $\mathrm{G}$ & $\mathrm{C}$ & $\mathrm{C}$ & G & $\mathrm{T}$ & $\mathrm{A}$ & $\mathrm{A}$ & $\mathrm{A}$ & $\mathrm{T}$ & $\mathrm{T}$ & A & $\mathrm{T}$ \\
\hline P2206 & TWK & G & $\mathrm{T}$ & $\mathrm{T}$ & A & $\mathrm{T}$ & $\mathrm{T}$ & G & $\mathrm{T}$ & $\mathrm{C}$ & G & $\mathrm{T}$ & A & A & A & $\mathrm{T}$ & $\mathrm{T}$ & A & $\mathrm{T}$ \\
\hline P2298 & TWK & G & $\mathrm{T}$ & $\mathrm{T}$ & A & $\mathrm{T}$ & $\mathrm{T}$ & G & $\mathrm{T}$ & C & G & $\mathrm{T}$ & A & A & A & $\mathrm{T}$ & $\mathrm{T}$ & A & $\mathrm{T}$ \\
\hline P2339 & TWK & G & $\mathrm{T}$ & $\mathrm{T}$ & A & $\mathrm{T}$ & $\mathrm{T}$ & G & $\mathrm{T}$ & $\mathrm{C}$ & G & NR & NR & NR & NR & NR & NR & NR & $\mathrm{NR}$ \\
\hline P2145 & TWK & G & $\mathrm{T}$ & A & A & $\mathrm{T}$ & $\mathrm{T}$ & G & $\mathrm{C}$ & $\mathrm{C}$ & G & $\mathrm{T}$ & A & A & A & $\mathrm{T}$ & $\mathrm{T}$ & A & $\mathrm{T}$ \\
\hline $\mathrm{P} 2145^{\mathrm{c}, \mathrm{d}}$ & unknown & G & $\mathrm{T}$ & $\mathrm{A}$ & $\mathrm{A}$ & $\mathrm{T}$ & $\mathrm{T}$ & $\mathrm{G}$ & $\mathrm{C}$ & $\mathrm{C}$ & G & $\mathrm{T}$ & $\mathrm{A}$ & $\mathrm{A}$ & A & $\mathrm{T}$ & $\mathrm{T}$ & $\mathrm{A}$ & $\mathrm{T}$ \\
\hline$\overline{\mathrm{P} 2331}$ & UK & $\mathrm{T}$ & $\mathrm{C}$ & $\mathrm{A}$ & $\mathrm{G}$ & $\mathrm{C}$ & $\mathrm{A}$ & $\mathrm{T}$ & $\mathrm{C}$ & $\mathrm{C}$ & $\mathrm{T}$ & $\mathrm{C}$ & $\mathrm{G}$ & $\mathrm{C}$ & $\mathrm{G}$ & $\mathrm{A}$ & $\mathrm{C}$ & $\mathrm{C}$ & $\mathrm{A}$ \\
\hline P2388 & UK & $\mathrm{T}$ & $\mathrm{C}$ & A & $\mathrm{G}$ & $\mathrm{C}$ & A & $\mathrm{T}$ & $\mathrm{C}$ & $\mathrm{C}$ & $\mathrm{T}$ & $\mathrm{C}$ & $\mathrm{G}$ & $\mathrm{C}$ & G & A & $\mathrm{C}$ & $\mathrm{C}$ & A \\
\hline P2311 & UK & $\mathrm{T}$ & $\mathrm{C}$ & A & $\mathrm{G}$ & $\mathrm{C}$ & A & $\mathrm{T}$ & $\mathrm{C}$ & $\mathrm{C}$ & $\mathrm{T}$ & $\mathrm{C}$ & G & $\mathrm{C}$ & G & A & $\mathrm{C}$ & $\mathrm{C}$ & A \\
\hline$\underline{\mathrm{P} 2331^{\mathrm{c}, \mathrm{d}}}$ & unknown & $\mathrm{T}$ & $\mathrm{C}$ & A & $\mathrm{G}$ & $\mathrm{C}$ & $\mathrm{A}$ & $\mathrm{T}$ & $\mathrm{C}$ & $\mathrm{C}$ & $\mathrm{T}$ & $\mathrm{C}$ & $\mathrm{G}$ & $\mathrm{C}$ & $\mathrm{G}$ & $\mathrm{A}$ & $\mathrm{C}$ & $\mathrm{C}$ & A \\
\hline P2397 & PNW & $\mathrm{T}$ & $\mathrm{T}$ & $\mathrm{A}$ & $\mathrm{G}$ & $\mathrm{C}$ & $\mathrm{A}$ & $\mathrm{T}$ & $\mathrm{C}$ & $\mathrm{C}$ & $\mathrm{T}$ & $\mathrm{C}$ & $\mathrm{G}$ & $\mathrm{C}$ & $\mathrm{G}$ & A & $\mathrm{C}$ & $\mathrm{C}$ & $\mathrm{T}$ \\
\hline P2060 & PNW & $\mathrm{T}$ & $\mathrm{T}$ & A & G & $\mathrm{C}$ & A & $\mathrm{T}$ & $\mathrm{C}$ & $\mathrm{C}$ & $\mathrm{T}$ & $\mathrm{C}$ & G & $\mathrm{C}$ & $\mathrm{G}$ & A & $\mathrm{C}$ & $\mathrm{C}$ & $\mathrm{T}$ \\
\hline P2457 & PNW & $\mathrm{T}$ & $\mathrm{T}$ & A & $\mathrm{G}$ & $\mathrm{C}$ & A & $\mathrm{T}$ & $\mathrm{C}$ & $\mathrm{C}$ & $\mathrm{T}$ & $\mathrm{C}$ & G & $\mathrm{C}$ & G & A & $\mathrm{C}$ & $\mathrm{C}$ & $\mathrm{T}$ \\
\hline P2459 & PNW & $\mathrm{T}$ & $\mathrm{T}$ & A & $\mathrm{G}$ & $\mathrm{C}$ & A & $\mathrm{T}$ & $\mathrm{C}$ & $\mathrm{C}$ & $\mathrm{T}$ & $\mathrm{C}$ & $\mathrm{G}$ & $\mathrm{C}$ & G & A & $\mathrm{C}$ & $\mathrm{C}$ & $\mathrm{T}$ \\
\hline $\mathrm{P} 2397^{\mathrm{c}, \mathrm{d}}$ & unknown & $\mathrm{T}$ & $\mathrm{T}$ & A & $\mathrm{G}$ & $\mathrm{C}$ & $\mathrm{A}$ & $\mathrm{T}$ & $\mathrm{C}$ & $\mathrm{C}$ & $\mathrm{T}$ & $\mathrm{C}$ & $\mathrm{G}$ & $\mathrm{C}$ & $\mathrm{G}$ & A & $\mathrm{C}$ & $\mathrm{C}$ & $\mathrm{T}$ \\
\hline$P 2060^{c, d}$ & unknown & $\mathrm{T}$ & $\mathrm{T}$ & A & $\mathrm{G}$ & $\mathrm{C}$ & A & $\mathrm{T}$ & $\mathrm{C}$ & $\mathrm{C}$ & $\mathrm{T}$ & $\mathrm{C}$ & $\mathrm{G}$ & $\mathrm{C}$ & $\mathrm{G}$ & A & $\mathrm{C}$ & $\mathrm{C}$ & $\mathrm{T}$ \\
\hline $\mathrm{P} 2457^{\mathrm{c}, \mathrm{d}}$ & unknown & $\mathrm{T}$ & $\mathrm{T}$ & A & G & $\mathrm{C}$ & A & $\mathrm{T}$ & $\mathrm{C}$ & $\mathrm{C}$ & $\mathrm{T}$ & $\mathrm{C}$ & G & $\mathrm{C}$ & G & A & $\mathrm{C}$ & $\mathrm{C}$ & $\mathrm{T}$ \\
\hline $\mathrm{P} 2459^{\mathrm{c}, \mathrm{d}}$ & unknown & $\mathrm{T}$ & $\mathrm{T}$ & A & G & $\mathrm{C}$ & $\mathrm{A}$ & $\mathrm{T}$ & $\mathrm{C}$ & $\mathrm{C}$ & $\mathrm{T}$ & $\mathrm{C}$ & $\mathrm{G}$ & $\mathrm{C}$ & $\mathrm{G}$ & $\mathrm{A}$ & $\mathrm{C}$ & $\mathrm{C}$ & $\mathrm{T}$ \\
\hline $\mathrm{PL}^{\mathrm{c}}$ & unknown & $\mathrm{T}$ & $\mathrm{T}$ & A & $\mathrm{G}$ & $\mathrm{C}$ & A & $\mathrm{T}$ & $\mathrm{C}$ & $\mathrm{C}$ & $\mathrm{T}$ & $\mathrm{C}$ & $\mathrm{G}$ & $\mathrm{C}$ & $\mathrm{G}$ & A & $\mathrm{C}$ & $\mathrm{C}$ & $\mathrm{T}$ \\
\hline JP-14-1 ${ }^{\mathrm{c}}$ & unknown & $\mathrm{T}$ & $\mathrm{T}$ & A & $\mathrm{G}$ & $\mathrm{C}$ & A & $\mathrm{T}$ & $\mathrm{C}$ & $\mathrm{C}$ & $\mathrm{T}$ & $\mathrm{C}$ & $\mathrm{G}$ & $\mathrm{C}$ & $\mathrm{G}$ & A & $\mathrm{C}$ & $\mathrm{C}$ & $\mathrm{T}$ \\
\hline$J P-14-2^{c}$ & unknown & $\mathrm{T}$ & $\mathrm{T}$ & A & G & $\mathrm{C}$ & A & $\mathrm{T}$ & $\mathrm{C}$ & $\mathrm{C}$ & $\mathrm{T}$ & $\mathrm{C}$ & G & $\mathrm{C}$ & $\mathrm{G}$ & A & $\mathrm{C}$ & $\mathrm{C}$ & $\mathrm{T}$ \\
\hline$J P-14-3^{c}$ & unknown & $\mathrm{T}$ & $\mathrm{T}$ & A & $\mathrm{G}$ & $\mathrm{C}$ & A & $\mathrm{T}$ & $\mathrm{C}$ & $\mathrm{C}$ & $\mathrm{T}$ & $\mathrm{C}$ & $\mathrm{G}$ & $\mathrm{C}$ & $\mathrm{G}$ & A & $\mathrm{C}$ & $\mathrm{C}$ & $\mathrm{T}$ \\
\hline JP-14-4 ${ }^{\mathrm{c}}$ & unknown & $\mathrm{T}$ & $\mathrm{T}$ & A & G & $\mathrm{C}$ & A & $\mathrm{T}$ & $\mathrm{C}$ & $\mathrm{C}$ & $\mathrm{T}$ & $\mathrm{C}$ & G & $\mathrm{C}$ & G & A & $\mathrm{C}$ & $\mathrm{C}$ & $\mathrm{T}$ \\
\hline $\mathrm{JP}-14-5^{\mathrm{c}}$ & unknown & $\mathrm{T}$ & $\mathrm{T}$ & A & G & $\mathrm{C}$ & A & $\mathrm{T}$ & $\mathrm{C}$ & $\mathrm{C}$ & $\mathrm{T}$ & $\mathrm{C}$ & $\mathrm{G}$ & $\mathrm{C}$ & $\mathrm{G}$ & A & $\mathrm{C}$ & $\mathrm{C}$ & $\mathrm{T}$ \\
\hline JP-14-6 & unknown & $\mathrm{T}$ & $\mathrm{T}$ & A & $\mathrm{G}$ & C & A & $\mathrm{T}$ & C & C & $\mathrm{T}$ & $\mathrm{C}$ & G & C & $\mathrm{G}$ & A & $\mathrm{C}$ & $\mathrm{C}$ & $\mathrm{T}$ \\
\hline JP-14-7 $7^{\mathrm{c}}$ & unknown & $\mathrm{T}$ & $\mathrm{T}$ & A & $\mathrm{G}$ & $\mathrm{C}$ & A & $\mathrm{T}$ & $\mathrm{C}$ & $\mathrm{C}$ & $\mathrm{T}$ & $\mathrm{C}$ & $\mathrm{G}$ & $\mathrm{C}$ & G & A & $\mathrm{C}$ & $\mathrm{C}$ & $\mathrm{T}$ \\
\hline$J P-15-23^{c}$ & unknown & $\mathrm{T}$ & $\mathrm{T}$ & A & G & $\mathrm{C}$ & A & $\mathrm{T}$ & $\mathrm{C}$ & $\mathrm{C}$ & $\mathrm{T}$ & $\mathrm{C}$ & G & $\mathrm{C}$ & $\mathrm{G}$ & $\mathrm{A}$ & $\mathrm{C}$ & $\mathrm{C}$ & $\mathrm{T}$ \\
\hline$J P-15-24^{c}$ & unknown & $\mathrm{T}$ & $\mathrm{T}$ & A & G & $\mathrm{C}$ & A & $\mathrm{T}$ & $\mathrm{C}$ & $\mathrm{C}$ & $\mathrm{T}$ & $\mathrm{C}$ & G & $\mathrm{C}$ & G & A & $\mathrm{C}$ & $\mathrm{C}$ & $\mathrm{T}$ \\
\hline$J P-15-25^{c}$ & unknown & $\mathrm{T}$ & $\mathrm{T}$ & A & G & $\mathrm{C}$ & A & $\mathrm{T}$ & $\mathrm{C}$ & $\mathrm{C}$ & $\mathrm{T}$ & $\mathrm{C}$ & G & $\mathrm{C}$ & G & A & $\mathrm{C}$ & $\mathrm{C}$ & $\mathrm{T}$ \\
\hline$J P-15-26^{c}$ & unknown & $\mathrm{T}$ & $\mathrm{T}$ & A & G & $\mathrm{C}$ & A & $\mathrm{T}$ & $\mathrm{C}$ & $\mathrm{C}$ & $\mathrm{T}$ & $\mathrm{C}$ & $\mathrm{G}$ & $\mathrm{C}$ & G & A & $\mathrm{C}$ & $\mathrm{C}$ & $\mathrm{T}$ \\
\hline $\mathrm{JP}-15-27^{\mathrm{c}}$ & unknown & $\mathrm{T}$ & $\mathrm{T}$ & A & G & C & A & $\mathrm{T}$ & C & C & $\mathrm{T}$ & $\mathrm{C}$ & G & C & G & A & C & $\mathrm{C}$ & $\mathrm{T}$ \\
\hline
\end{tabular}

${ }^{a}$ Nucleotides indicated in light grey are identical to that of the PNW lineage (reference isolates P2397, P2060, P2457, and P2459); nucleotides indicated in dark grey differ from the PNW lineage. For isolates of known lineage, sequences are taken from Brasier et al. (2012). NR = no record.

${ }^{\mathrm{b}}$ Lineage, when known, as published by Brasier et al. (2012); isolates of unknown lineage include those from E. Hansen, included as a control to compare to published sequences, the wildlands isolate, and nursery isolates.

${ }^{\mathrm{c}}$ Isolates for which we sequenced the $\operatorname{cox} 1$ and $\operatorname{cox} 2$ regions.

${ }^{\mathrm{d}}$ Extracts for these isolates were obtained from E. Hansen. 
and 117490. Clones OSU-CF1 and 117490 display single-gene resistance; COS30839 displays quantitative resistance and is classified as having "slow-to-die" mortality patterns (Robin et al. 2015) (R. Sniezko, personal communication).

In addition to the three isolates used in the Koch's postulates trial, we randomly selected an additional isolate from J. communis (JP-141) and M. decussata (JP-14-7) for the virulence experiments, for five isolates total (Table 1). The branch-dip experiment was performed twice, in June 2016 and March 2018. Due to concerns regarding reduced virulence of PL3 as a result of storage, all isolates were inoculated onto POC, then reisolated prior to use between the first and second branch dip trial.

For each trial, 1-m-long branches were clipped from clonally propagated trees maintained at the Bureau of Land Management Tirell seed orchard in Oregon. After being stored overnight in plastic bags at $4^{\circ} \mathrm{C}$, branch tips were cut to a length of approximately $30 \mathrm{~cm}$, and the cut stems were immersed in DI water until inoculation. We removed foliage from the bottom $10 \mathrm{~cm}$ of each branch; then, the branches of the different clones were tagged and evenly distributed among 1-liter glass jars, each containing $100 \mathrm{ml}$ of zoospore suspension of a single isolate. For each trial, we diluted each zoospore suspension with DI water to match that of the most dilute isolate, ranging between $2 \times 10^{3}$ and $1.25 \times 10^{4}$ zoospores $/ \mathrm{ml}$ (second and first trial, respectively). Immersing the cut ends of the branches into the zoospore suspension raised the depth of the liquid to $1 \mathrm{~cm}$. An additional control treatment containing $100 \mathrm{ml}$ of DI water was also included. For each isolate, we used 10 branch tips per clone.

Two days after inoculation at $20^{\circ} \mathrm{C}$, we removed the branch tips and placed them into individual plastic growth cones containing packed, wet perlite (Supreme Perlite Co., Portland, OR, U.S.A.), which were placed on grow racks. The racks were placed in a growth chamber and maintained between 20 and $25^{\circ} \mathrm{C}$ with $10 \mathrm{~h}$ of light and daily watering. After 3 weeks, the cuttings were removed from the perlite and rinsed, and the outer bark was scraped to reveal discoloration of the inner bark characteristic of Phytophthora infection. We recorded lesion length on the longest side and plated the upper edge of the lesion margin on PAR from a subset of branches for each clone-isolate combination to confirm infection by $P$. lateralis.

A generalized least-squares model was used to test for differences in lesion length between each POC clone and isolate, and for differential response by isolates between trials. We performed posthoc

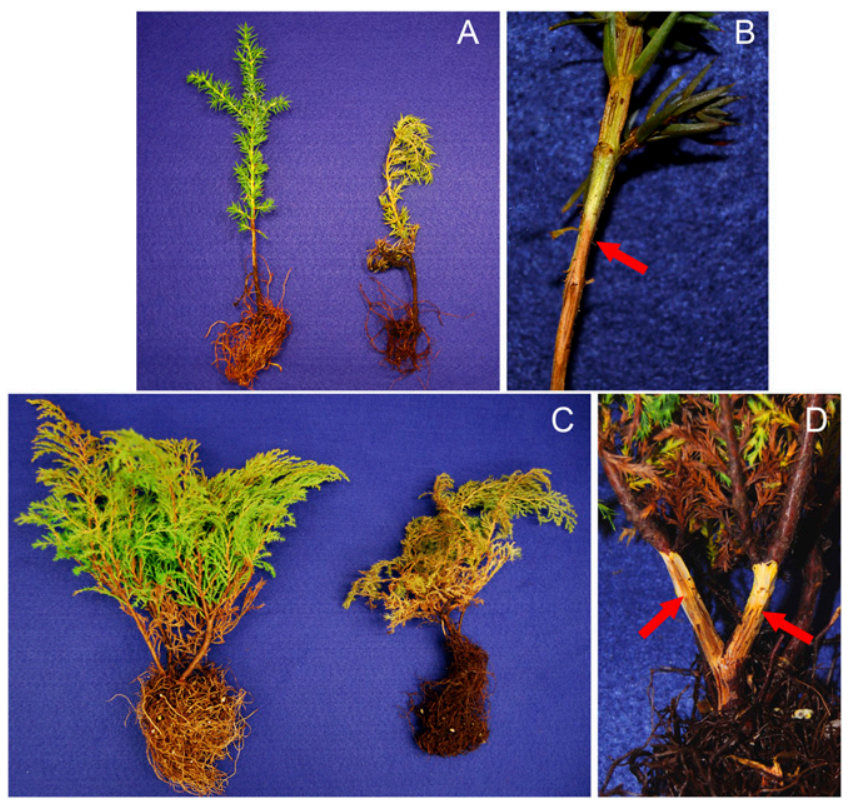

Fig. 2. Healthy (left) and symptomatic (right) plants demonstrating Phytophthora lateralis infection of $\mathbf{A}$ and $\mathbf{B}$, Juniperus communis 'Blueberry Delight' and $\mathbf{C}$ and $\mathbf{D}$, Microbiota decussata 'Celtic Pride' postinoculation with nursery-recovered isolates or deionized water. Symptoms on both include chlorosis, root necrosis, and collar lesions. Lesion margins from which we isolated $P$. lateralis are indicated with an arrow. analysis to determine differences between clones separately for each isolate with a Fischer's least significant difference test. All analyses were performed in R, ver. 3.4.3 (R Core Team 2015).

Resistance to mefenoxam. Resistance to mefenoxam was assessed in an assay utilizing agar plates amended with Subdue MAXX. Four different concentrations were tested: mefenoxam at $0.1,1,10$, or $100 \mu \mathrm{g} / \mathrm{ml}$, with three replicates per treatment per isolate. To produce the plates, we first made concentrated stock solutions, one for each concentration. Stock solution $(10 \mathrm{ml})$ was then added to $650 \mathrm{ml}$ of autoclaved 1/3 V8 media (clarified V8 broth at $77 \mathrm{ml} /$ liter buffered with $\mathrm{CaCO}_{3}$ at $1.28 \mathrm{~g} /$ liter) after it had cooled to $50^{\circ} \mathrm{C}$. The media was set on a stir plate for $5 \mathrm{~min}$ prior to pouring. We added $10 \mathrm{ml}$ of autoclaved DI water to the media as a nonamended control. A single 3-mm plug taken from the leading edge of colonies from each $P$. lateralis isolate (Table 1) was placed on the center of the plate; plates were placed in the dark at $20^{\circ} \mathrm{C}$. After 10 days, we measured colony diameter in two perpendicular directions, which was then averaged. Growth was assessed for all isolates by calculating diameter as a percentage of the control for that isolate. This experiment was repeated with new stock solutions for each trial.

\section{Results}

Species and lineage determination. Twelve $P$. lateralis isolates were obtained from J. communis 'Blueberry Delight' or $M$. decussata (Table 1). ITS sequences ( $>740$ bp long) had greater than $99 \%$ sequence similarity to $P$. lateralis. Sporangia for all cultures were ovoid to obpyriform, with occasional internal proliferation, ranging between an average \pm standard error (SE) of $54.2 \pm 2.3 \mu \mathrm{m}$ (JP14-5 isolate) to $62.7 \pm 3.4 \mu \mathrm{m}$ (PL3 isolate) in length and $27.1 \pm$ $0.9 \mu \mathrm{m}$ (JP-14-5 isolate) to $28.9 \pm 0.9 \mu \mathrm{m}$ (JP-14-7 isolate) in width. Chlamydospores were intercalary or lateral along hyphae, occasionally terminal, with average \pm SE diameter ranging between $32.7 \pm$ $2.0 \mu \mathrm{m}$ (PL3 isolate) and 48.5 $\pm 2.5 \mu \mathrm{m}$ (JP-14-1 isolate). Chlamydospores were within the range expected for $P$. lateralis; sporangia were slightly larger than reported by Tucker and Milbrath (1942), although $P$. lateralis reference isolate PL3 was the longest and nearly the widest of those measured. Oogonia were not observed.

Control isolates (P2271, P2145, P2331, P397, P2060, P2457, and $\mathrm{P} 2459)$ were correctly placed in their published lineages, having $\operatorname{cox} 1$ and $\operatorname{cox} 2$ sequences identical to those published by Brasier et al. (2012) (Table 2). All nursery isolates were placed in the PNW lineage, being indistinguishable from published and reference PNW isolates (Table 2). All sequences were deposited in GenBank (accession numbers MK780082 to MK780093 for ITS sequences and MK792723 to MK792746 for cox sequences).

Pathogenicity tests: Koch's postulates. Symptoms characteristic of Phytophthora infection were observed on all hosts, including chlorosis, root necrosis, collar lesions, and mortality (Fig. 2; Table 3). Overall, greater mortality was observed for plants inoculated with the nursery isolates in comparison with the PL3 isolate (Table 3). $P$. lateralis was successfully reisolated from both stems and roots for each host-isolate combination for which we observed symptoms. Though we did not observe disease development on J. communis when inoculated with isolate PL3, we were able to isolate $P$. lateralis from the roots or collar of two of the three randomly selected plants. No isolates were recovered from the DI water control plants. We confirmed the identity of all sequenced isolates recovered from pathogenicity trials as $P$. lateralis.

Pathogenicity tests: Virulence on POC. For the branch-dip inoculation, all $P$. lateralis isolates were recovered from all clones despite limited lesion development on some clone-isolate combinations; $P$. lateralis was not isolated from negative controls treated with DI water. Lesions developed on OSU-CON1 for all isolates; lesion length varied by isolate, with PL3 being the least aggressive and isolates JP-14-7, JP-14-5, and JP-14-1 being the most aggressive (Fig. 3).

A trial-isolate interaction was observed $(P<0.001)$ whereby, in the second trial isolates JP-15-23, JP-14-7, and JP-14-5 caused relatively larger lesions on all clones and isolate PL3 caused larger lesions only on COS30839 (data not shown). Regardless, rankings of the clones' susceptibility and of the nursery isolates in comparison 
with PL3 were similar when each trial was analyzed separately, and data were combined for analysis. Lesion lengths differed significantly between one or more isolates $(P<0.0001)$, and differences between isolates depended upon which clone was inoculated $(P<$ 0.0001). Overall, resistant clones OSU-CF1 and 117490 had the shortest lesions for any given isolate in both trials; substantial lesion development on 117490 was only observed with the nursery isolates (Fig. 3). Lesion lengths were significantly shorter on the COS30839 clone than OSU-CON1 when inoculated with the PL3 only (Fig. 3).

Resistance to mefenoxam. Minimal hyphal growth of Juniperus or Microbiota isolates occurred on agar plates amended with mefenoxam (Fig. 4). Growth at any concentration was observed for only four isolates: JP-15-25, JP-14-4, JP-14-5, and JP-14-7; growth with mefenoxam at $0.1 \mu \mathrm{g} / \mathrm{ml}$ ranged between an average of 1.69 and $2.79 \%$ of that for the nonamended control plates (corresponding to 98.31 and $97.21 \%$ inhibition, respectively). No growth of any isolates was detected on plates amended with mefenoxam at 10 or $100 \mu \mathrm{g} / \mathrm{ml}$ (Fig. 4).

\section{Discussion}

The addition of new conifer genera as hosts to $P$. lateralis highlights the continued threat of this and other invasive Phytophthora spp. to wildland health management. $P$. lateralis has a multidecade history in the Pacific Northwest. Nonetheless, new hosts highly susceptible to $P$. lateralis are still being discovered and many questions remain regarding its potential impact on these hosts in their native environments. Fortunately, in this case, there is no evidence that the current isolates are of a new lineage or possess resistance to mefenoxam. These isolates were, however, more aggressive than the wildlands isolate currently being used to screen POC, raising concerns about the long-term durability of resistance in the face of continued introduction of new isolates by the nursery industry.

We completed Koch's postulates of P. lateralis on both $M$. decussata and J. communis. For any given isolate, the greatest disease was observed on POC, followed by M. decussata and J. communis. Overall, the least amount of disease was observed for isolate PL3, which did not cause substantial symptoms on J. communis. We were able, however, to recover isolate PL3 from this host. Recovery of Phytophthora spp. from the roots of symptomless hosts is a documented phenomenon for other pathogenic species (Crone et al. 2013; Fichtner et al. 2011; Junker et al. 2016; Vercauteren et al. 2013). Likely this is a result of PL3 being a less aggressive isolate than the others used in the assay.

It is unlikely that decreased aggressiveness by PL3 resulted from long-term storage. PL3 was one of two isolates being used to screen POC as part of the resistance breeding program at the time of our first trials; however, based on our results from the Koch's postulates test, we chose to pass all isolates through POC for their use in the second branch-dip trial. Although lesion lengths produced by PL3 were slightly larger on some clones in the second trial, the second branch dip was consistent with our first observation that PL3 is less aggressive than the nursery isolates, particularly JP-14-7, JP-14-5, and JP14-1.

Resistance scoring of the different POC clones was consistent with prior studies; for any given isolate, smaller lesion lengths were observed on the most-resistant clone 117490 and the largest lesions on most-susceptible clone OSU-CON1. There was no evidence that the more aggressive nursery isolates overcame resistance of CF1 or 117490 and, although we observed no resistance in clone COS30839 when inoculated with some nursery isolates, lesion sizes were similarly larger when using the PL3 and JP-15-23 isolates. The lack of evidence for resistance in clone $\operatorname{COS} 30839$ when inoculated with JP-14-7, JP-14-5, and JP-14-1 might be partly attributable to our use of a branch assay, which is only used for preliminary screening of resistance. Resistance might be more apparent with a root-dip assay utilizing seedlings or rooted cuttings, a method which typically follows the preliminary branch-dip screening and is more proficient at discerning levels of resistance (Robin et al. 2015). With the current assay, we find no immediate concern for overcoming resistance in long-established resistant clones CF1 and 117490, although these

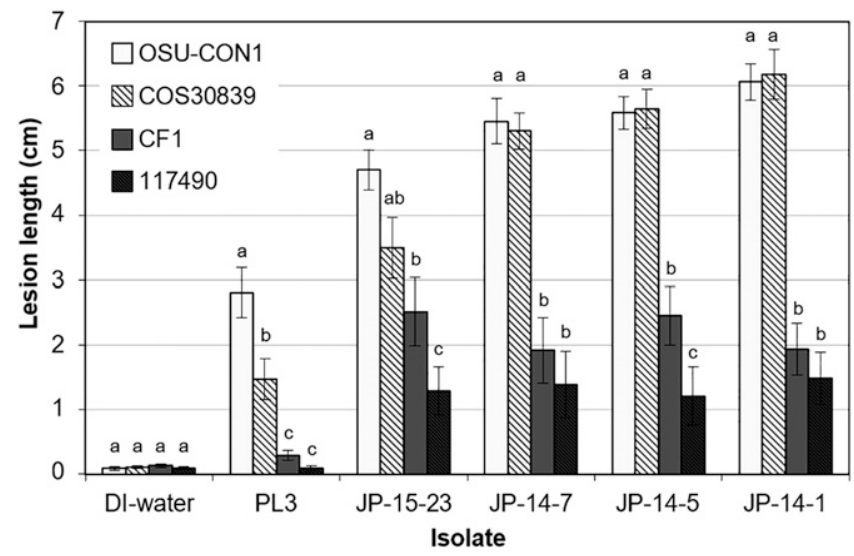

Fig. 3. Average lesion length along Port-Orford-cedar (POC) branches inoculated with one of five Phytophthora lateralis isolates or a deionized (DI) water control. Data are combined for the two trials; bars represent standard error. Letters above each bar indicate significant differences between POC clones within a single isolate.

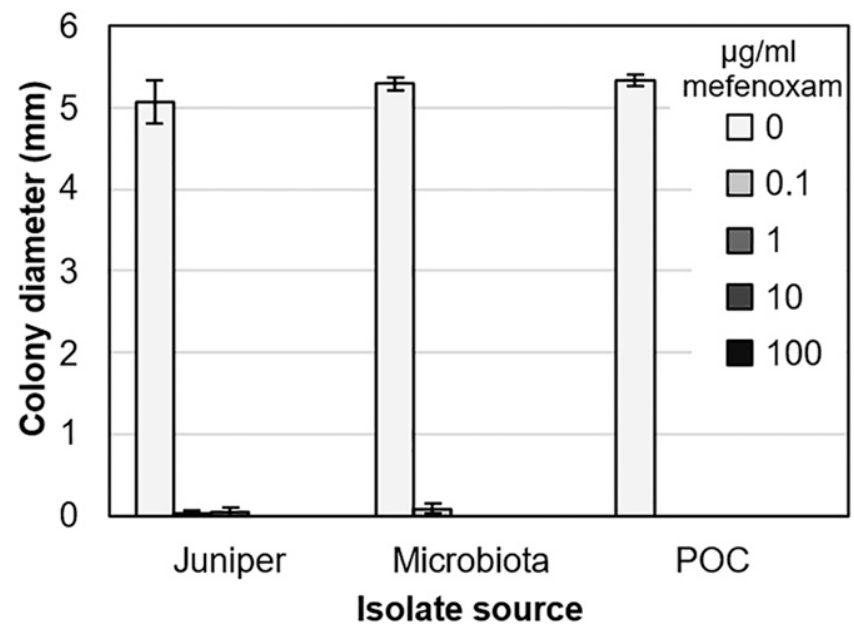

Fig. 4. Average colony diameter (bars represent standard error) for isolates grown on agar plates amended with Subdue MAXX at concentrations of mefenoxam ranging between 0.1 and $100 \mu \mathrm{g} / \mathrm{ml}$, or a nonamended control. Data are combined for the two replicate trials, and are presented combining juniper isolates $(n=5)$, microbiota isolates $(n=6)$, or Port-Orford-cedar (POC) isolate $(n=1)$.

Table 3. Average ( \pm standard error) disease rating score for seedlings inoculated with each of the Phytophthora lateralis isolates

\begin{tabular}{llccc}
\hline & & & Host $^{\mathbf{a}}$ \\
\cline { 3 - 5 } Isolate & \multicolumn{1}{c}{ Source host } & POC clone OSU-CON1 & $\begin{array}{c}\text { Microbiota decussata } \\
\text { 'Celtic Pride' }\end{array}$ & $\begin{array}{c}\text { Juniperus communis } \\
\text { 'Blueberry Delight' }\end{array}$ \\
\hline PL3 & Chamaecyparis lawsoniana & $1.60(0.16)$ & $1.13(0.09)$ & $0(0)$ \\
JP-15-23 & M. decussata & $2.0(0)$ & $1.47(0.13)$ & NT \\
JP-14-5 & J. communis & $1.80(0.13)$ & NT & $1.23(0.12)$ \\
\hline
\end{tabular}

${ }^{\text {a }}$ POC $=$ Port-Orford-cedar. Scoring: $0=$ healthy, $1=$ symptomatic, $2=$ dead, and NT $=$ not tested. 
more aggressive isolates should be adopted into the screening process.

Fortunately, these isolates are from the PNW lineage already established in the region, though it raises questions regarding the source of the inoculum and why disease on Juniperus and Microbiota spp. was only reported recently. It is very unlikely that inoculum was recently introduced from outside the nursery, via importation of nursery stock or through dispersal from adjacent horticultural POC; it is possible, however, that infection first established on nursery-propagated Chamaecyparis spp. before spreading to and causing disease on these other conifer genera. We hypothesized that the recent disease manifestation could be attributed to the development of mefenoxam resistance, commonly assessed as the concentration required to reduce culture diameter to (typically) 50\% that of the controls $\left(\mathrm{EC}_{50}\right)$.

Reported $\mathrm{EC}_{50}$ values for various Phytophthora spp. range between $<0.1$ and $>500 \mu \mathrm{g} / \mathrm{ml}$ ( $\mathrm{Hu}$ et al. 2008; Hwang and Benson 2005; Olson et al. 2013; Parra and Ristaino 2001; Pérez-Sierra et al. 2011; Taylor et al. 2002). Cutoffs vary; however, isolates have been classified as sensitive with, for example, over $50 \%$ inhibition on plates amended with mefenoxam at 0.1 to $1.0 \mu \mathrm{g} / \mathrm{ml}$ (Hu et al. 2008; Taylor et al. 2002). In comparison, $\mathrm{EC}_{50}$ values of $100 \mu \mathrm{g} / \mathrm{ml}$ are reported as having functional resistance in vivo (Hu et al. 2008; Lamour and Hausbeck 2003). That some minimal growth on mefenoxam-containing medium was observed in some nursery isolates but not the wildlands isolate could be expected given their prior exposure to mefenoxam; however, by any measure, all $P$. lateralis isolates in this study would be classified as sensitive.

Given the repeated application of Subdue MAXX in these nurseries, the sensitivity of nursery isolates to mefenoxam was surprising. It is possible that plants were infected prior to application, or that a spray rotation using fungicides with different modes of action suppressed tolerant isolates. We may also have missed resistant isolates, given that a mix of tolerant and susceptible isolates have been reported in most surveys and our sample size was small relative to other studies (Hu et al. 2008; Hwang and Benson 2005; Olson et al. 2013; Parra and Ristaino 2001; Patel et al. 2016; Taylor et al. 2002). Resistance appears to be more prevalent on annual crops than perennials (Hu et al. 2008; Olson et al. 2013); thus, resistance may occur at a low frequency on Juniperus or Microbiota spp. Regardless, isolates were capable of causing significant disease despite the application of Subdue MAXX at these nurseries. Improper or delayed nursery applications during a high-risk period for disease development may have allowed previously infected plants to display symptoms, especially because mefenoxam is fungistatic rather than fungicidal (Chastagner et al. 2010; Linderman and Davis 2008).

It is highly likely that $P$. lateralis is more widespread than acknowledged within conifer nurseries, even if they do not grow POC. Genus Microbiota was particularly susceptible. Endemic to the Sikhote Alin mountains of southeastern Siberia, Microbiota decussata is a relatively recent introduction into the U.S. horticultural industry (Farjon 2017; Rose 2005). Also known as Siberian cypress or Russian cypress, these plants have been clonally propagated and available since around the 1980s (Farjon 2017). Thus far, P. cinnamomi is the only recorded species isolated from Microbiota spp., recovered from horticultural nurseries in Poland (Orlikowski 2010). Genus Juniperus is host to multiple Phytophthora spp., including P. cinnamomi (Standish et al. 1982) and P. austrocedri, a species currently causing significant juniper dieback in native wildlands in Britain (Green et al. 2014). Prior reports have indicated that Juniperus spp. may be susceptible to P. lateralis (Abad et al. 1994; Green and Webber 2015); however, in one, P. lateralis was likely misidentified and other reports remain unverified. To date, this is the first completion of Koch's postulates confirming $P$. lateralis infection of any Juniperus sp.

Apart from Taxus, other host genera Microbiota, Juniperus, Thuja, and Chamaecyparis are all within the same subfamily, the Cupressoideae (Gadek et al. 2000), which is consistent with prior assertions that infection by $P$. lateralis is generally limited to hosts within the family Cupressaceae (Erwin and Ribeiro 1996). Other genera in the subfamily Cupressoideae-Calocedrus, Cupressus, Fokienia, Platycladus, and Thujopsis-should be evaluated as potential hosts to $P$. lateralis, notably as asymptomatic carriers.

Symptoms of Phytophthora root rot are easily mistaken for other agents or abiotic conditions, particularly when nursery managers are not familiar with the genus Phytophthora. Only in the wake of multiple introductions of invasive Phytophthora spp. have researchers, regulatory agencies, and industry fully come to appreciate the extent to which this genus is established in and is moved by horticultural nurseries (Jung et al. 2015; Liebhold et al. 2012; Parke et al. 2014; Yakabe et al. 2009). New hosts (e.g., Juniperus and Microbiota spp.) and etiologies (e.g., foliar infection) present a challenge to managing $P$. lateralis, whereby cryptic spread, reintroductions, and novel dispersal mechanisms may negate the positive gains of the POC resistance breeding program, especially if new lineages are introduced. All parties should be conscientious of the need to manage Phytophthora spp. to reduce the spread and establishment of $P$. lateralis and other Phytophthora spp.

\section{Acknowledgments}

We thank two anonymous nurseries for their cooperation during this study; E. Hansen, P. Reeser, and W. Sutton (Oregon State University) for DNA extracts for the lineage determination, and for advice necessary to complete plant inoculations; and R. Sniezko and E. Hooten (DGRC) for assistance in producing POC-CON1 plants and collecting POC branches, and insight into the POC resistance breeding program. Lastly, we would like to acknowledge Eric Larson, Katie Pardee, and Anna Burton for technical assistance.

\section{Literature Cited}

Abad, Z. G., Creswell, T., Jones, R. K., and Shew, H. D. 1994. Occurrence of Phytophthora species on various hosts in North Carolina. Plant Dis. 78:830.

Betlejewski, F., Casavan, K. C., Dawson, A., Goheen, D. J., Mastrofini, K., Rose, D. L., and White, D. E., eds. 2003. A range-wide assessment of Port-Orfordcedar (Chamaecyparis lawsoniana) on federal lands. U.S. Department of Agriculture, Forest Service, and U.S. Department of the Interior, Bureau of Land Management, Portland, OR.

Brasier, C. M., Franceschini, S., Vettraino, A. M., Hansen, E. M., Green, S., Robin, C., Webber, J. F., and Vannini, A. 2012. Four phenotypically and phylogenetically distinct lineages in Phytophthora lateralis. Fungal Biol. 116:1232-1249.

Brasier, C. M., Vannini, A., Chang, T. T., and Vettraino, A. M. 2010. Phytophthora lateralis discovered in an old growth Chamaecyparis forest in Taiwan. Plant Pathol. 59:595-603.

Chastagner, G. A., DeBauw, A., and Riley, K. 2010. Effect of fungicides on the isolation of Phytophthora ramorum from symptomatic and asymptomatic rhododendron leaf tissue. Pages 302-304 in: Proc. Sudden Oak Death Fourth Sci. Symp. S. J. Frankel, J. T. Kliejunas, and K. M. Palmieri, eds. Gen. Tech. Rep. PSW-GTR-214. U.S. Department of Agriculture, Forest Service, Pacific Southwest Research Station, Albany, CA, U.S.A.

Cooke, D. E. L., Drench, A., Duncan, J. M., Wagels, G., and Brasier, C. M. 2000 A molecular phylogeny of Phytophthora and related oomycetes. Fungal Genet. Biol. 30:17-32.

Crone, M., McComb, J. A., O’Brien, P. A., and Hardy, G. E. 2013. Survival of Phytophthora cinnamomi as oospores, stromata, and thick-walled chlamydospores in roots of symptomatic and asymptomatic annual and herbaceous perennial plant species. Fungal Biol. 117:112-123.

DeNitto, G. A., and Kliejunas, J. T. 1991. First report of Phytophthora lateralis on Pacific yew. Plant Dis. 75:968.

Erwin, D. C., and Ribeiro, O. K. 1996. Phytophthora Diseases Worldwide. American Phytopathological Society Press, St. Paul, MN, U.S.A.

Farjon, A. 2017. Pages 532-533 in: A Handbook of the World's Conifers, Vol. 1 second revised ed. Brill Academic Publishers, Leiden, The Netherlands.

Fichtner, E. J., Rizzo, D. M., Kirk, S. A., and Webber, J. F. 2011. Root infections may challenge management of invasive Phytophthora spp. in U.K. woodlands. Plant Dis. 95:13-18.

Gadek, P. A., Alpers, D. L., Heslewood, M. M., and Quinn, C. J. 2000 Relationships within Cupressaceae sensu lato: A combined morphological and molecular approach. Am. J. Bot. 87:1044-1057.

Green, S., Brasier, C. M., Schlenzig, A., McCracken, A., MacAskill, G. A., Wilson, M., and Webber, J. F. 2013. The destructive invasive pathogen Phytophthora lateralis found on Chamaecyparis lawsoniana across the UK. For. Pathol. 43:19-28.

Green, S., Elliot, M., Armstrong, A., and Hendry, S. J. 2014. Phytophthora austrocedrae emerges as a serious threat to juniper (Juniperus communis) in Britain. Plant Pathol. 64:456-466.

Green, S., and Webber, J. F. 2015. Pest risk analysis for Phytophthora lateralis, revised version 3. Forest Research UK. https://secure.fera.defra.gov.uk/phiw/ riskRegister/downloadExternalPra.cfm?id=4050 
Hansen, E. M., Goheen, D. J., Jules, E. S., and Ullian, B. 2000. Managing PortOrford-cedar and the introduced pathogen Phytophthora lateralis. Plant Dis. 84:4-14.

Hansen, E. M., Hamm, P. B., and Roth, L. F. 1989. Testing Port-Orford-cedar for resistance to Phytophthora. Plant Dis. 73:791-794.

Hansen, E. M., Streito, J.-C., and Delatour, C. 1999. First confirmation of Phytophthora lateralis in Europe. Plant Dis. 83:587.

Hu, J. H., Hong, C. X., Stromberg, E. L., and Moorman, G. W. 2008. Mefenoxam sensitivity and fitness analysis of Phytophthora nicotianae isolates from nurseries in Virginia, USA. Plant Pathol. 57:728-736.

Hwang, J., and Benson, D. M. 2005. Identification, mefenoxam sensitivity, and compatibility type of Phytophthora spp. attacking floriculture crops in North Carolina. Plant Dis. 89:185-190.

Jung, T., Orlikowski, L., Henricot, B., Abad-Campos, P., Aday, A. G., Aguín Casal, O., Bakonyi, J., Cacciola, S. O., Cech, T., Chavarriaga, D., Corcobado, T., Cravador, A., Decourcelle, T., Denton, G., Diamandis, S., Dogmus-Lehtijärvi, H. T., Franceschini, A., Ginetti, B., Glavendekic, M., Hantula, J., Hartmann, G., Herrero, M., Ivic, D., Horta Jung, M., Lilja, A., Keca, N., Kramarets, V., Lyubenova, A., Machado, H., Magnano di San Lio, G., Mansilla Vázquez, P. J., Marçais, B., Matsiakh, I., Milenkovic, I., Moricca, S., Nagy, Z. Á., Nechwatal, J., Olsson, C., Oszako, T., Pane, A., Paplomatas, E. J., Pintos Varela, C., Prospero, S., Rial Martínez, C., Rigling, D., Robin, C., Rytkönen, A., Sánchez, M. E., Scanu, B., Schlenzig, A., Schumacher, J., Slavov, S., Solla, A., Sousa, E., Stenlid, J., Talgø, V., Tomic, Z., Tsopelas, P., Vannini, A., Vettraino, A. M., Wenneker, M., Woodward, S., and Peréz-Sierra, A. 2015. Widespread Phytophthora infestations in European nurseries put forest, semi-natural and horticultural ecosystems at high risk of Phytophthora diseases. For. Pathol. 46:134-163.

Junker, C., Goff, P., Wagner, S., and Werres, S. 2016. Occurrence of Phytophthora in commercial nursery production. Plant Health Prog. 17:64-75.

Lamour, K. H., and Hausbeck, M. K. 2003. Susceptibility of mefenoxam treated cucurbits to isolates of Phytophthora capsici sensitive and insensitive to mefenoxam. Plant Dis. 87:920-922.

Liebhold, A. M., Brockerhoff, E. G., Garrett, L. J., Parke, J. L., and Britton, K. O. 2012. Live plant imports: The major pathway for forest insect and pathogen invasions of the US. Front. Ecol. Environ. 10:135-143.

Linderman, R. G., and Davis, E. A. 2008. Evaluation of chemical agents for the control of Phytophthora ramorum and other species of Phytophthora on nursery crops. Plant Health Prog. 9

Martin, F. N., and Tooley, P. W. 2003. Phylogenetic relationships among Phytophthora species inferred from sequence analysis of mitochondrially encoded cytochrome oxidase I and II genes. Mycologia 95:269-284.

Murray, M. S., and Hansen, E. M. 1997. Susceptibility of Pacific yew to Phytophthora lateralis. Plant Dis. 81:1400-1404.

Olson, H. A., Jeffers, S. N., Ivors, K. L., Steddom, K. C., Williams-Woodward, J. L., Mmbaga, M. T., Benson, D. M., and Hong, C. X. 2013. Diversity and mefenoxam sensitivity of Phytophthora spp. associated with the ornamental horticulture industry in the southeastern United States. Plant Dis. 97:86-92.

Orlikowski, L. B. 2010. Occurrence and harmfulness of Phytophthora spp. in Polish hardy ornamental nursery stock. Acta Hortic. 885:243-248.

Parke, J. L., Knaus, B. J., Fieland, V. J., Lewis, C., and Grünwald, N. J. 2014. Phytophthora community structure analyses in Oregon nurseries inform systems approaches to disease management. Phytopathology 104:1052-1062.

Parra, G., and Ristaino, J. B. 2001. Resistance to mefenoxam and metalaxyl among field isolates of Phytophthora capsici causing Phytophthora blight of bell pepper. Plant Dis. 85:1069-1075.
Patel, J. S., Vitoreli, A., Palmateer, A. J., El-Sayed, A., Norman, D. J., Goss, E. M., Brennan, M. S., and Ali, G. S. 2016. Characterization of Phytophthora spp. isolated from ornamental plants in Florida. Plant Dis. 100:500-509.

Pérez-Sierra, A., Álvarez, L. A., Vercauteren, A., Heungens, K., and AdabCampos, P. 2011. Genetic diversity, sensitivity to phenylamide fungicides and aggressiveness of Phytophthora ramorum on Camellia, Rhododendron, and Viburnum plants in Spain. Plant Pathol. 60:1069-1076.

R Core Team. 2015. R: A Language and Environment for Statistical Computing. R Foundation for Statistical Computing, Vienna, Austria. http://www.R-project.org/

Robin, C., Brasier, C., Reeser, P., Sutton, W., Vannini, A., Vettraino, A. M., and Hansen, E. 2015. Pathogenicity of Phytophthora lateralis lineages on different selections of Chamaecyparis lawsoniana. Plant Dis. 99:1133-1139.

Robin, C., Piou, D., Feau, N., Douzon, G., Schenck, N., and Hansen, E. M. 2010 Root and aerial infections of Chamaecyparis lawsoniana by Phytophthora lateralis: A new threat for European countries. For. Pathol. 41:417-424.

Rose, N. 2005. Microbiota decussata: A versatile conifer. Arnoldia 63:15-16.

Schlenzig, A., Campbell, R., and Eden, R. 2014. First report of Phytophthora lateralis on Chamaecyparis pisifera. New Dis. Rep. 29:15.

Schlenzig, A., Campbell, R., and Mulholland, V. 2011. Thuja occidentalis: A new host for Phytophthora lateralis. New Dis. Rep. 24:8.

Schlenzig, A., Campbell, R. B., and Roberts, A. M. I. 2017. The susceptibility of selected conifer foliage to infection with Phytophthora lateralis. For. Pathol. 47:e12333.

Sniezko, R. A., and Hansen, E. M. 2001. Breeding Port-Orford-cedar for resistance to Phytophthora lateralis: Current status \& considerations for developing durable resistance. Pages 197-201 in: 'Phytophthora in Forests and Natural Ecosystems'. 2nd Int. IUFRO Work. Party 7.02.09 Meet., Albany, Western Australia. J. A. McComb, G. E. StJ Hardy, and I. C. Tommerup, eds. Murdoch University Print.

Sniezko, R. A., and Koch, J. 2017. Breeding trees resistant to insects and diseases: Putting theory into application. Biol. Invasions 19:3377-3400.

Standish, E. D., MacDonald, J. D., and Humphrey, W. A. 1982. Phytophthora root and crown rot of junipers in California. Plant Dis. 66:925-928.

Taylor, R. J., Salas, B., Secor, G. A., Rivera, V., and Gudmestad, N. C. 2002 Sensitivity of North American isolates of Phytophthora erythroseptica and Pythium ultimum to mefenoxam (metalaxyl). Plant Dis. 86:797-802.

Tucker, C. M., and Milbrath, J. A. 1942. Root rot of Chamaecyparis caused by a species of Phytophthora. Mycologia 34:94-103.

van der Gaag, D. J., and Meffert, J. 2013. Pest risk assessment of Phytophthora lateralis. Netherlands Food and Consumer Product Safety Authority. https:// english.nvwa.nl/documents/plant/plant-health/pest-risk-analysis/documents/ pest-risk-analysis-phytophthora-lateralis

Vercauteren, A., Riedel, M., Maes, M., Werres, S., and Heungens, K. 2013 Survival of Phytophthora ramorum in Rhododendron root balls and in rootless substrates. Plant Pathol. 62:166-176.

White, T. J., Bruns, T., Lee, S., and Taylor, J. 1990. Amplification and direct sequencing of fungal ribosomal RNA genes for phylogenetics. Pages 315-322 in: PCR Protocols: A Guide to Methods and Applications. M. A Innis, D. H. Gelfand, J. J. Sninsky, and T. J. White, eds. Academic Press, San Diego, CA, U.S.A.

Yakabe, L. E., Blomquist, C. L., Thomas, S. L., and MacDonald, J. D. 2009 Identification and frequency of Phytophthora species associated with foliar diseases in California ornamental nurseries. Plant Dis. 93:883-890.

Zobel, D. B., Roth, L. F., and Hawk, G. M. 1985. Ecology, pathology, and management of Port-Orford-cedar (Chamaecyparis lawsoniana). Gen. Tech. Rep. PNW-GTR-184. U.S. Department of Agriculture, Forest Service, Pacific Northwest Research Station, Portland, OR, U.S.A 